\title{
PENGARUH ACARA PARIWISATA OLAHRAGA, CITRA DESTINASI HALAL, DAN NILAI YANG DIRASAKAN TERHADAP NIAT BERPERILAKU WISATAWAN UNTUK BERKUNJUNG KEMBALI, MEREKOMENDASIKAN KEPADA ORANG LAIN DAN POSITIF WOM
}

\author{
Baiq Nadia Nirwana ${ }^{1}$, Sulhaini ${ }^{2}$, Lalu Edy Herman Mulyono ${ }^{3}$ \\ 1Program Studi Magister Manajemen Fakultas Ekonomi dan Bisnis Unram, \\ E-mail: baiqnadianirwana@gmail.com \\ ${ }^{2}$ FakultasEkonomi dan Bisnis, Universitas Mataram. \\ E-mail: sulhaini@unram.ac.id \\ ${ }^{3}$ FakultasEkonomi dan Bisnis, Universitas Mataram. \\ E-mal : ehlalu@yahoo.com
}

\begin{tabular}{|c|c|}
\hline ARTICLE INFO & ABSTRACT \\
\hline $\begin{array}{l}\text { Keywords: } \\
\text { Event Sport Tourism, Halal Destination Image, } \\
\text { Perceived Value, Behavioral Intentions. } \\
\text { Kata Kunci: } \\
\text { Event Sport Tourism, Citra Destinasi Halal, } \\
\text { Persepsi Nilai, Behavioral Intentions } \\
\text { How to cite: } \\
\text { Nirwana, Baiq Nadia., Sulhaini.,Mulyono, Lalu } \\
\text { Edy Herman., (2020). Pengaruh Acara } \\
\text { Pariwisata Olahraga, Citra Destinasi Halal, } \\
\text { Dan Nilai Yang Dirasakan Terhadap Niat } \\
\text { Berperilaku Wisatawan Untuk Berkunjung } \\
\text { Kembali, Merekomendasikan Kepada Orang } \\
\text { Lain Dan Positif WOM. JMM UNRAM, 9(4a), } \\
81-95 \text { WOI : } \\
\text { http://dx.doi.org/10.29303/imm.v9i4a.612 }\end{array}$ & $\begin{array}{l}\text { This study aims to examinethe influence of sport } \\
\text { tourism events, halal destination image, and perceived } \\
\text { value on behavioral intentions of tourists at the } \\
\text { Mandalika International Marathon event. Data } \\
\text { collection was carried out among both active and } \\
\text { passive participants of the Mandalika International } \\
\text { Marathon by using the associative quantitative } \\
\text { method. Furthermore, the data collected was analyzed } \\
\text { further. This study uses structural equation modeling } \\
\text { analysis (SEManalysis) with AMOS applications. The } \\
\text { results of the study indicated that sport tourism events } \\
\text { haves a significant positive effect on behavioral } \\
\text { intentions, and the halal destination image has a } \\
\text { significant positive effect on perceived value. The West } \\
\text { Nusa Tenggara government is supported event } \\
\text { organizers to develop halal tourism and sport tourism } \\
\text { events. This is to enhance, halal destination image in } \\
\text { NTB is not only for religious tourism. } \\
\text { Penelitian ini bertujuan untuk menjelaskan seberapa } \\
\text { besar pengaruh antara Event Sport Tourism, Citra } \\
\text { Destinasi Halal, dan Perceived Value terhadap } \\
\text { Behavioral Intentions Wisatawan pada Event } \\
\text { Mandalika International Marathon. Pengumpulan } \\
\text { data dilakukan pada peserta ajtifmaupun peserta pasif } \\
\text { Event Mandalika International Marathon dengan } \\
\text { menggunakan metode kuantitatif asosiatif. } \\
\text { Selanjutnya data yang terkumpul dianalisis lebih }\end{array}$ \\
\hline
\end{tabular}




\begin{tabular}{|l|l|}
\hline & lanjut. Penelitian ini menggunakan analisis model \\
& persamaan struktural (analisis SEM) dengan aplikasi \\
AMOS. Hasil penelitian membuktikan bahwa Event \\
Sport Tourism berpengaruh positif signifikan terhadap \\
& Behavioral Intentions, dan Citra Destinasi Halal \\
berpengaruh positif signifikan terhadap Perceived \\
Value. Pemerintah Nusa Tenggara Barat perlu \\
mendukung upaya-upaya para penyelenggara event \\
& dalam mengembangkan pariwisata halal dan event \\
& sport tourism, agar citra destinasi wisata halal yang \\
ada di NTB tidak hanya untuk wisata-wisata religi \\
saja. \\
\hline \\
Copyright@ 2020. Baiq Nadia Nirwana, Sulhaini, \\
LaluEdy Herman Mulyono. All rights reserved.
\end{tabular}

\section{PENDAHULUAN}

Pariwisata olahraga merupakan salah satu sektor dengan pertumbuhan tercepat dalam industri pariwisata (Gibson, 1998). Salah satu contoh yang paling mencolok adalah pada Olimpiade Barcelona 1992. Event ini dapat menarik hampir setengah juta pengunjung ke wilayah tersebut (Truno, 1994). Perpaduan antara pariwisata dan olahraga dirasakan mampu meningkatkan behavioral intentions wisatawan. Kepala Dinas Kebudayaan dan Pariwisata NTB (2016) mengatakan bahwa pertumbuhan pariwisata olahraga di NTB saat ini, terus mengalami perkembangan yang positif sehingga akan menghadirkan event sport tourism yang disinergikan dengan kalender agenda wisata. Selain pengembangan pariwisata melalui event sport tourism, NTB juga melakukan branding "Pariwisata Halal". Hal ini dikarenakanNTB sudah mendapatkan pengakuan dunia melalui penghargaan World Best Halal Tourism Destination dan World Best Halal Honeymoon Destination dari World Halal Travel Awards (WHTA).

Battour dan Ismail (2016) mendefinisikan pariwisata halal sebagai obyek wisata yang diperbolehkan dalam ajaran Islam untuk dipergunakan umat muslim dalam kaitannya di industri pariwisata.NTB yang saat ini dikenal sebagai destinasi wisata halal, dapat dijadikan brand merk "Citra Destinasi Halal" dalam event sport tourism untuk menjadi daya tarik tersendiri bagi wisatawan. Citra destinasi halal adalah salah satu cara yang dapat dilakukan dalam mengembangkan pariwisata olahraga berbasis syari'ah, sebagai bentuk dakwah. Gohary (2016) mengatakan bahwa citra destinasi halal sesuai syariat Islam harus mencakup ketersediaan makanan dan fasilitas halal, tidak ada penyediaan minuman beralkohol, tidak ada hiburan malam, pemisahan fasilitas umum antara laki-laki dan perempuan beserta pelayanannya. Hal tersebut sesuai dengan para atlet yang membutuhkan rasa nyaman pada saat mengikuti event olahraga. Dengan adanya produk halal dapat menjadi jaminan sehat bagi para atlet muslim maupun non-muslim yang terbiasa menerapkan pola hidup sehat dalam kehidupan sehari-hari.

Hasil penelitian (Jin, Lee, \& Lee, 2013) menunjukkan faktor lain yang dapat mempengaruhi behavioral intentions wisatawan dalam event sport tourism adalah perceived value. Perceived value merujuk pada evaluasi konsumen terhadap produk dan jasa. Perceived valuedidefinisikan sebagai utilitas yang berasal dari produk nyata atau layanan tak berwujud, ini terdiri dari apa manfaat yang didapat individu dan biaya apa yang harus mereka bayar.Beberapa hasil penelitian juga menunjukkan bahwa event sport tourism secara signifikan mempengaruhi citra destinasi, citra destinasi berpengaruh positif dan signifikan 
terhadap perceived value dan perceived value juga berpengaruh positif signifikan terhadap behavioral intentions (Cipta \& Farida, 2018; Fu, Liu, Wang, \& Chao, 2018; Jeong, Kim, \& Yu, 2019; Jin, Lee, \& Lee, 2013; Yohanes, 2018). Sedangkan menurut (Jin, Lee, \& Lee, 2013; Jin, Lee, \& Lee, 2015; Kim, Lee, Petrick, \& Hahn, 2018), pengaruh dari perceived value dan citra destinasi terhadap behavioral intention tidak menunjukkan effect signifikan. Hasil penelitian lain menunjukkan bahwa perceived value berpengaruh signifikan terhadap citra destinasi dan behavioral intention namun citra destinasi tidak berpengaruh signifikan terhadap behavioral intention (Kim, Lee, Petrick \& Hahn, 2018).

Penelitian-penelitian yang pernah dilakukan sebelumnya yaitu tentang pengaruh event sport tourism, citra destinasi, perceived value terhadap behavioral intentions menunjukkan temuan yang belum konsisten dari hasil penelitian. Belum ada penelitian sebelumnya yang mengaitkan event sport tourism dengan pariwisata halal, sehingga upaya menggabungkan antara event sport tourism, citra destinasi halal yang dimediasi perceived valuemenjadi menarik untuk diteliti. Penelitian ini bertujuan untuk menjelaskan seberapa besar pengaruh event sport tourism, citra destinasi halal, perceived value terhadap behavioral intentions pada event Mandalika International Marathon.

\section{KAJIAN PUSTAKA}

\subsection{Event Sport Tourism}

Sektor event sport tourism telah menjadi pasar yang tumbuh tercepat di industri pariwisata di seluruh dunia. (Gibson, 1998) mendefinisikan event sport tourism menjadi sebuah citra dalam menarik orang-orang yang melakukan perjalanan dengan tujuan untuk bersantai atau ikut berkompetisi. Sebagian orang bahkan rela meninggalkan kesibukan dan menyediakan waktu luang untuk ikut berpartisipasi hanya untuk sekedar menjadi penonton atau menjadi peserta dalam kompetisi. Dengan adanya event sport tourism tentunya akan mengundang turis dari berbagai daerah dan negara. Kesuksesan sebuah event tidak hanya di nilai dari bagaimana penyelenggara (daerah) memberikan atau mengemas acara sebaik mungkin, akan tetapi juga di nilai dari sisi niat dan minat pengunjung. Disini promosi merupakan salah satu alat yang paling efektif untuk mengembangkan dan memperkenalkan acara lokal untuk dapat dikenal oleh masyarakat luar. Acara yang baik dan memuaskan tentunya akan membuat pengunjung untuk berkunjung kembali dan tidak hanya datang sekali saja (Annisa, 2016).

Menurut Afrilian (2018) event sport tourism bukanlah hal baru dalam masyarakat karena beberapa moment penting biasanya selalu menghadirkan acara dengan berisikan berbagai pertandingan dan perlombaan olahraga. Event sport tourism juga berpotensi sebagai ajang hiburan, event olahraga memang bersifat atraktif sehingga jika dikemas secara baik dan profesional, maka akan bernilai sehingga dari daya atraktif tersebut akan diminati oleh masyarakat.

\subsection{Citra Destinasi Halal}

Pariwisata halal adalah sebuah industry jasa yang belakangan menjadi salah satu pusat perhatian di banyak Negara, baik dikalangan para pengusaha jasa maupun para peneliti (Battour \& Ismail, 2016). Pariwisata adalah bagian dari dakwah. Untuk non-Muslim, tur syariah dengan produk halal adalah jaminan sehat. Karena diprinsipnya, implementasi aturan halal artinya menghapus hal - hal yang membahayakan kemanusiaan dan lingkungan dalam produk dan layanan yang disediakan, dan tentu memberikan kebaikan atau manfaat secara umum. 
Saat ini Lombok sudah dikenal sebagai citra destinasi halal melalui penghargaan World Best Halal Tourism Destination dan World Best Halal Honeymoon Destination dari World Halal Travel Awards (WHTA). Menurut Kaur, Chauhan \& Medury (2016) citra destinasi adalah jumlah dari keyakinan, ide dan tayangan yang orang miliki akan suatu tempat atau destinasi. Dapat disimpukan bahwa citra destinasi merupakan timbal balik dari wisatawan atas apa yang dirasakan baik melalui pengalaman maupun informasi yang diterima, dapat berupa kesan, pendapat komentar dan perasaan terhadap suatu destinasi wisata.

Citra destinasi yang positif akan memberikan keyakinan kepada wisatawan untuk melakukan kunjungan kembali pada destinasi pariwisata tersebut. Pencitraan yang baik tentu akan menarik minat wisatawan untuk datang berkunjung, sebaliknya pencitraan yang buruk akan membuat destinasi pariwisata menjadi terpuruk (Indira, Ismanto \& Santoso, 2013:47). Citra destinasi halal adalah salah satu cara yang bisa kita lakukan dalam membangun citra wisata halal pada event sport tourism.

\subsection{Perceived Value}

Perceived Value merupakan penukaran yang menjadi pokok dalam pemasaran dengan nilai sebagai pengukur yang tepat dari penukaran apapun baik pantas maupun tidak (Kotler dan Keller, 2011). Sederhananya perceived value adalah manfaat yang dirasakan. Jadi, produk dikatakan memiliki nilai yang tinggi jika sesuai dengan kebutuhan, keinginan, dan permintaan pelanggan (Kotler dan Keller, 2011). Kebanyakan peneliti mendefinisikan perceived value sebagai dasar persepsi konsumen dalam evaluasi mereka yang membandingkan antara manfaat yang mereka terima dari penyedia layanan dengan pengorbanan yang mereka keluarkan uantuk mendapatkan layanan tersebut (Woodruff, 1997).

Peningkatan perceived value akan meningkatkan behavioral intentions to revisit, atau penilaian penunjung pengunjung meningkat maka meningkatkan niat berkunjung kembali di masa mendatang. Sehingga, persepsi nilai dianggap sebagai determinan penting dalam meningkatkan behavioral intentions (Chen \& Chen, 2010).

\subsection{Behavioral Intentons (untuk berkunjung kembali, merekomendasikan kepada orang lain dan positif WOM)}

Terkait dengan pemasaran, Menurut Zeithaml, Berry, and Parasuraman (1996) menjelaskan bahwa niat berperilaku dapat berupa pembelian ulang, word of mouth, komplain dan sensitifitas harga. Menurut Chen \& Tsai (2007). Penelitian mengoperasionalkan niat perilaku menggunakan tiga variabel: niat untuk kembali, kesediaan untuk merekomendasikan, dan positif word of mouth (WOM) (Prayag, Hosany \& Odeh 2013).

Keinginan berperilaku (behavioral intention) dapat didefinisikan sebagai keinginan konsumen untuk berperilaku menurut cara tertentu dalam rangka memiliki, membuang, dan menggunakan produk atau jasa. Jadi, konsumen dapat membentuk keinginan untuk mencari informasi, memberitahukan orang lain tentang pengalamannya dengan sebuah produk, membeli produk atau jasa tertentu, atau membuang produk dengan cara tertentu (Mowen \& Minor, 2002:322). Dengan demikian, niat perilaku dalam penelitian ini, mengacu pada kemungkinan yang dinyatakan untuk kembali ke tujuan dan di masa depan, merekomendasikan tujuan kepada keluarga, teman, dan positif word of mouth (WOM).

\subsection{Hubungan Antar Variabel.}

Promosi parwisata seringkali menggunakan media film untuk menarik turis, tetapi cara mempromosikan ini tidak akan mempercepat jumlah turis. Menurut Paramitha \& 
Sukirman (2019) strategi untuk meningkatkan jumlah wisatawan lebih cepat, yaitu event sport tourism, karena orang-orang memiliki sikap nasionalis sehingga mereka akan mendukung atlet yang mewakili negara mereka. Hal ini akan menjadi aspek penting yang membuat orang-orang berperilaku mengunjungi acara-acara olahraga sewaktu mengadakan pariwisata.

Sementara banyak penelitian meneliti peran penting event dalam mempengaruhi perceived value pelanggan dan perilaku konsekuen (Chen \& Chen, 2010), sedikit empiris Penelitian membahas hubungan eksplisit antara kualitas event dan perceived value. Jin, Lee, \& Lee (2013) mengemukakan dan secara empiris menguji hubungan antara kualitas event, citra destinasi dan perceived value memiliki efek positif dan memverifikasi logika yang mendasarinya dampak kognisi pada emosi dan menegaskan kualitas event dan perceived value adalah anteseden dari niat perilaku, berlaku untuk konteks acara olahraga. Temuan mereka event sport tourism memiliki peran penting di dalam memberikan perceived value yang baik terhadap citra destinasi suatu objek wisata sehingga dapat memunculkan niat berperilaku berkunjung kembali wisatawan (behavioral intentions to revisit) karena mampu memberikan pengalaman kepada wisatawan yang mengikuti event maupun penonton dari event tersebut.

Selanjutnya Chen dan Chen (2010) meneliti hubungan antara experience quality dan perceived value. Temuan mereka menunjukkan bahwa persepsi pengunjung tentang kualitas pengalaman dari warisan pariwisata menentukan perceived value mereka. Belum lama ini (Cipta \& Farida, 2018) menemukan bahwa dimensi destination image mengenaikerapian, kebersihan objek wisata dan kesan positif yang diperoleh saat kunjungan berpengaruh positif signifikan terhadap variabel perceived value serta behavioral intentions wisatawan.

Ada konsensus untuk memberikan bukti bahwa kualitas event, dan khususnya elemen inti, adalah variabel kunci karena secara langsung memprediksi behavioral intentions peserta (Milovanović, et al., 2019). Jeong, Kim, \& Yu (2019) menunjukkan manfaat kualitas event dalam penelitian yang bertujuan untuk lebih memahami dan memprediksi perilaku wisatawan, sedangkan penelitian sebelumnya hampir secara eksklusif mempertimbangkan citra destinasi dan kepuasan wisatawan sebagai penentu niat perilaku.

Selain itu, Lita (2015) menyimpulkan bahwa kepuasan terhadap sport event berpengaruh terhadap behavioral intentions to revisit. Maka disarankan kepada pihak penyelenggara sport event benar-benar berupaya memberikan kualitas event yang baik sehingga memberikan kepuasan kepada wisatawan yang menonton sport event tersebut, sehingga menimbulkan intensi kepada wisatawan untuk berkunjung kembali dan merekomendasikan kepada orang lain tentang sport event.

Selanjutnya dari hasil penelitian (Lita \& Ma'ruf, 2014) ditemukan bahwa kepuasan terhadap sport event berpengaruh positif terhadap intensi berkunjung kembali dan kepuasan terhadap sport event berpengaruh positif terhadap intense untuk positive word-of-mouth. Hal ini mengindikasikan bahwa kepuasan wisatawan yang menonton sport event mampu meningkatkan behavioral intentions wisatawan di masa yang akandatang yaitu intensi untuk mengunjungi kembali destinasi wisata dan mau merekomendasikan kepada orang lain (teman dan keluarga). Oleh karena itu pihak penyelenggara sport event benar-benar berupaya memberikan kualitas event yang baik sehingga memberikankepuasan kepada wisatawan yang menonton sport event tersebut. Temuan dari literatur membentuk dasar untuk mengajukan hipotesis:

H1 : Semakin sering event sport tourism maka semakin bagus perceived value pada kunjungan wisatawan ke event Mandalika International Marathon. 
H2 : Semakin bagus citra destinasi halal maka semakin bagus pula perceived value pada kunjungan wisatawan ke event Mandalika International Marathon.

H3 : semakin sering event sport tourism maka semakin tinggi behavioral intentions pada kunjungan wisatawan ke event Mandalika International Marathon.

Dalam rangka meningkatkan niat mengunjungi kembali acara, penelitian ini menekankan bahwa penyelenggara acara harus fokus pada pembangunan citra positif dari acara tersebut (Hussein, 2016).

Hasil penelitian (Milovanović, et al., 2019) memberikan bukti bahwa citra destinasi adalah variabel yang tidak boleh diabaikan oleh pembuat kebijakan ketika memutuskan di mana acara harus direncanakan. Itu ditunjukkan bahwa destination image mempengaruhi baik secara langsung maupun tidak langsung pengembangan niat perilaku, yang diukur dengan niat atlet untuk mengunjungi tujuan di masa depan dan mengembangkan kata-kata positif dari mulut ke mulut. Dalam penelitian pariwisata, studi empiris menunjukkan bahwa beberapa faktor penting, seperti citra destinasi (Destari, 2017) destinasi independen dan kepuasan wisatawan (Samsudin, 2016) berdampak langsung pada behavioral intentions, dan para peneliti tersebut menunjukkan bahwa konstruk behavioral intentions sepenuhnya dapat memprediksi perilaku orangmeskipun kepuasan tidak terukur.

Selanjutnya Kristanti \& Farida (2015) menyatakan bahwa citra destinasi berpengaruh positif terhadap kepuasan pengunjung. Kepuasan berpengaruh positif terhadap niat berperilaku pengunjung Museum Kereta Api Ambarawa. Berdasarkan hasil analisis diketahui bahwa variabel citra destinasi berpengaruh positif terhadap niat berperilaku dengan variabel kepuasan menjadi variabel intervening.Williem (2019) menyatakan citra destinasi tidak hanya berpengaruh positif dan signifikan terhadap perceived value tetapi juga berpengaruh positif signifikan terhadap behavioral intentions. Adanya pengaruh positif berarti semakin meningkat perceived value maka akan meningkatkan behavioral intentions to revisit.

Selanjutnya hasil penelitiam (Cipta \& Farida, 2018; Fu, Liu, Wang, \& Chao, 2018) menemukan perceived value berpengaruh positif dan signifikan terhadap behavioral intentions. Sedangkan menurut Kim, Lee, Petrick, \& Hahn (2018), citra destinasi tidak berpengaruh positif dan signifikan terhadap behavioral intentions. Citra destinasi memiliki efek positif signifikan pada perceived value tetapi tidak memiliki behavioral intentions. Akhirnya perceived value memiliki pengaruh positif signifikan pada behavioral intentions (Jin, Lee \& Lee,2013). Menurut Jin, Lee \& Lee (2015) pengaruh dari perceived value dan destination image terhadap behavioral intention tidak menunjukkan effect signifikan. Banyak peneliti setuju perceived value memberikan pengaruh signifikan pada behavioral intentions wisatawan (Chen \& Chen, 2010) H4 : Semakin bagus citra destinasi halal maka semakin tinggi behavioral intentions pada kunjungan wisatawan ke event Mandalika International Marathon.

H5 : Semakin bagus perceived value maka semakin tinggi behavioral intentions pada kunjungan wisatawan ke event Mandalika International Marathon.

Beberapa hasil penelitian sebelumnya telah membuktikan adanya hubungan antar variabel, hanya saja terdapat beberapa perbedaan, misalnya : indikator pengukur tiap variabel dan hasil penelitian. Kemudian setiap penelitian mempunyai kelemahan dan belum ada yang meneliti hubungan antar variabel seperti yang akan diteliti peneliti tentang event sport tourism yang dikaitkan dengan pariwisata halal. 


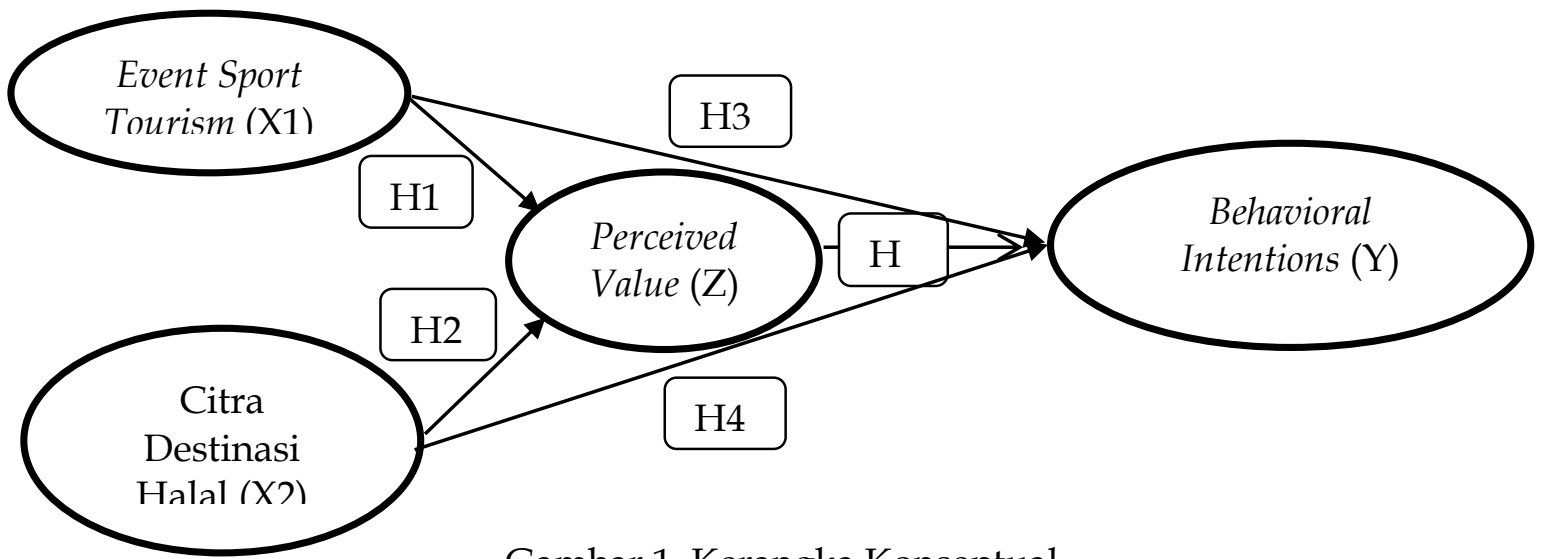

Gambar 1. Kerangka Konseptual

\section{METODE PENELITIAN}

Pendekatan penelitian ini menggunakan pendekatan kuantitatif dengan pendekatan asosiatif. Populasi dalam penelitian ini adalah seluruh peserta aktif maupun peserta pasif pada event Mandalika International Marathon. Teknik penentuan sampel yang digunakan adalah purposive sampling. Purposive sampling merupakan teknik penentuan sampel berdasarkan pertimbangan tertentu, yang dianggap cocok dengan karakteristik sampel yang ditentukan akan dijadikan sampel. Kriteria pengambilan sampel adalah : a) Berusia antara 18-35 tahun. b) Tidak bertempat tinggal di daerah pelaksanaan event. Besarnya sampel yang digunakan adalah sebanyak 120 orang.Teknik analisis data yang akan digunakan adalah SEM atau Structural Equation Modelling yang dioperasikan melalui program AMOS.

Tabel 1 Hasil Uji Validitas

\begin{tabular}{|l|l|c|c|c|}
\hline Variabel & \multicolumn{1}{|c|}{ Pernyataan } & r-hitung & Keputusan & Keterangan \\
\hline & $\begin{array}{l}\text { Menarik untuk mengikuti atau } \\
\text { menyaksikan event tersebut }\end{array}$ & 0,596 & Valid & r-hit $>$ r-tab \\
\cline { 2 - 5 } & $\begin{array}{l}\text { Informasi tentang event ini mudah } \\
\text { diperoleh }\end{array}$ & 0,541 & Valid & r-hit $>$ r-tab \\
\cline { 2 - 5 } Event \\
$\begin{array}{l}\text { sikap panitia penyelenggara } \\
\text { menyenangkan } \\
\text { tourism }\end{array}$ & $\begin{array}{l}\text { Saya senang berada bersama dengan } \\
\text { peserta/penonton lain dari berbagai } \\
\text { asal yang berbeda }\end{array}$ & 0,626 & Valid & r-hit $>$ r-tab \\
\cline { 2 - 5 } & $\begin{array}{l}\text { Seluruh peserta mengikuti } \\
\text { peraturan yang berlaku }\end{array}$ & 0,59 & Valid & r-hit $>$ r-tab \\
\cline { 2 - 5 } & $\begin{array}{l}\text { Saya melihat hasil akhir event ini } \\
\text { positif }\end{array}$ & 0,685 & Valid & r-hit $>$ r-tab \\
\cline { 2 - 5 } & $\begin{array}{l}\text { Saya benar-benar menikmati event } \\
\text { ini }\end{array}$ & 0,692 & Valid & r-hit $>$ r-tab \\
\cline { 2 - 5 } & $\begin{array}{l}\text { Saya menghabiskan waktu yang } \\
\text { berkualitas dengan teman/keluarga } \\
\text { pada event ini. }\end{array}$ & 0,571 & Valid & r-hit $>$ r-tab \\
\hline
\end{tabular}




\begin{tabular}{|c|c|c|c|c|}
\hline & $\begin{array}{l}\text { Suasana lokasi pertandingan adalah } \\
\text { apa yang saya cari }\end{array}$ & 0,606 & Valid & r-hit $>$ r-tab \\
\hline & $\begin{array}{l}\text { Lingkungan bersih dan terawat } \\
\text { dengan baik }\end{array}$ & 0,537 & Valid & r-hit $>r-$ tab \\
\hline & $\begin{array}{l}\text { Saya terkesan dengan desain } \\
\text { fasilitas event }\end{array}$ & 0,575 & Valid & r-hit $>$ r-tab \\
\hline & Fasilitas-fasilitas tersebut aman & 0,604 & Valid & r-hit $>$ r-tab \\
\hline \multirow{4}{*}{$\begin{array}{l}\text { Citra } \\
\text { destinasi } \\
\text { halal }\end{array}$} & $\begin{array}{l}\text { Terdapat tempat ibadah di sekitar } \\
\text { lokasi event }\end{array}$ & 0,317 & Valid & r-hit $>$ r-tab \\
\hline & $\begin{array}{l}\text { Adanya pemisahan tempat bagi } \\
\text { peserta dan penonton laki-laki } \\
\text { dengan perempuan }\end{array}$ & 0,453 & Valid & r-hit $>$ r-tab \\
\hline & $\begin{array}{l}\text { Adanya pemisahan tim medis untuk } \\
\text { peserta laki-laki dan perempuan. }\end{array}$ & 0,574 & Valid & r-hit $>$ r-tab \\
\hline & $\begin{array}{l}\text { Makanan dan minuman yang ada di } \\
\text { sekitar lokasi event terjamin } \\
\text { kehalalannya }\end{array}$ & 0,308 & Valid & r-hit $>$ r-tab \\
\hline \multirow{4}{*}{$\begin{array}{l}\text { Perceived } \\
\text { value }\end{array}$} & $\begin{array}{l}\text { Biaya yang dikeluarkan sesuai } \\
\text { dengan kualitas event }\end{array}$ & 0,573 & Valid & r-hit $>$ r-tab \\
\hline & $\begin{array}{l}\text { Penyelenggaraan event ini sangat } \\
\text { berkualitas }\end{array}$ & 0,679 & Valid & r-hit $>$ r-tab \\
\hline & $\begin{array}{l}\text { Waktu yang saya habiskan di event } \\
\text { ini membuat saya merasa bahagia }\end{array}$ & 0,462 & Valid & r-hit $>$ r-tab \\
\hline & $\begin{array}{l}\text { Kualitas event didukung oleh } \\
\text { profesionalitas penyelenggara }\end{array}$ & 0,578 & Valid & r-hit $>$ r-tab \\
\hline \multirow{3}{*}{$\begin{array}{l}\text { Behavioral } \\
\text { intention }\end{array}$} & $\begin{array}{l}\text { Saya ingin kembali ke event ini di } \\
\text { masa yang akan dating }\end{array}$ & 0,633 & Valid & r-hit $>$ r-tab \\
\hline & $\begin{array}{l}\text { Saya akan merekomendasikan event } \\
\text { dan destinasi ini kepada teman- } \\
\text { teman dan keluarga saya atau orang } \\
\text { lain }\end{array}$ & 0,826 & Valid & r-hit $>$ r-tab \\
\hline & $\begin{array}{l}\text { Saya ingin memberi tahu hal-hal } \\
\text { positif yang saya dapatkan pada } \\
\text { event ini }\end{array}$ & 0,627 & Valid & r-hit $>$ r-tab \\
\hline
\end{tabular}

Tabel 2 Hasil Uji Reliabilitas

\begin{tabular}{|c|l|c|c|c|}
\hline No & \multicolumn{1}{|c|}{ Variabel } & $\begin{array}{c}\text { Cronbach's } \\
\text { alpha (a) }\end{array}$ & Keputusan & Keterangan \\
\hline 1 & Event sport tourism & 0,892 & Reliabel & $\mathrm{a}>0,7$ \\
\hline 2 & Citra destinasi halal & 0,713 & Reliabel & $\mathrm{a}>0,7$ \\
\hline 3 & Perceived value & 0,767 & Reliabel & $\mathrm{a}>0,7$ \\
\hline 4 & Behavioral intentions & 0,828 & Reliabel & $\mathrm{a}>0,7$ \\
\hline
\end{tabular}

\section{Karakteristik Responden}

Setelah mendapat persetujuan, peserta menanggapi kuesioner yang diberikan. Dalam penelitian ini, $74,2 \%$ responden adalah laki-laki dan $25,8 \%$ adalah perempuan. 
Sebagian besar responden bekerja sebagai PNS/TNI/POLRI (44\%), 33\% sebagai wiraswasta dan sisanya (23\%) sebagai pelajar/mahasiswa. Orang NTB menyumbang 71\% dari sampel, mewakili kategori daerah asal terbesar di antara responden, diikuti oleh responden dari Jawa sebanysk 15\%, dari Jakarta sebesar 3\%, Bali 5\%, Papua 0,9\% kemudian Sumatera, Sulawesi dan NTT 1,7\%. Untuk agama, sebanyak $82 \%$ responden adalah muslim dan $18 \%$ merupakan nonmuslim. Di antara responden, 84\% mengikuti event sebagai peserta aktif dan 16\% mengikuti event sebagai peserta pasif/penonton.

\section{HASIL DAN PEMBAHASAN}

\subsection{Analisis Data}

Pengujian SEM dengan program AMOS memberikan hasil model persamaan struktural yang menunjukkan hubungan antar variabel laten seperti pada Gambar 2. berikut ini:

\section{Gambar 2.Hasil Analisis SEM Model Hipotesis Penelitian}

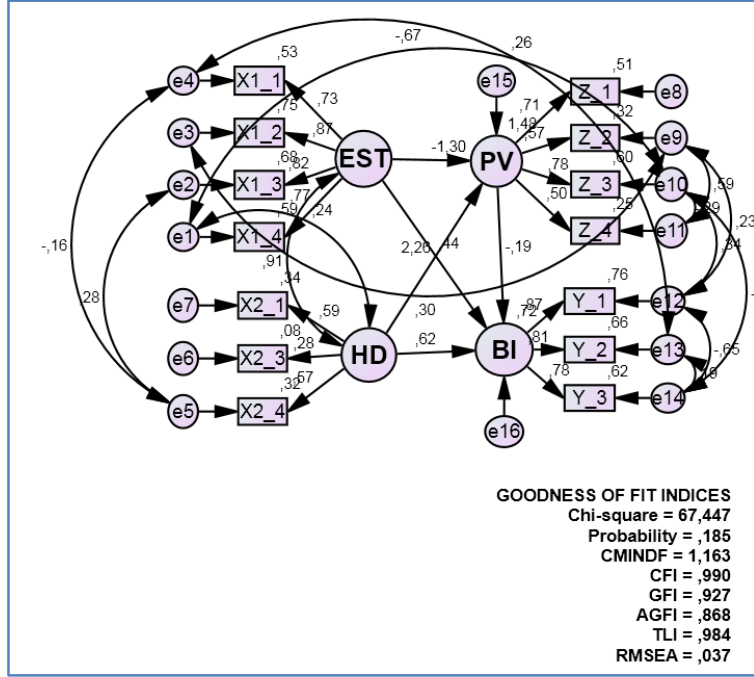

Pengujian model pada SEM bertujuan untuk melihat kesesuaian model.Berdasarkan hasil pengujian kesesuaian model yang disajikan dalam Tabel 1, diketahui bahwa dari delapan kriteria yang digunakan untuk menilai layak atau tidaknya suatu model, ternyata seluruh kriteria terpenuhi. Dengan demikian dapat dikatakan model dapat diterima yang berarti ada kesesuaian antara model dengan data dalam penelitian ini.

Tabel 2.Indeks Kesesuaian SEM

\begin{tabular}{|l|c|c|c|}
\hline Goodness of Fit Indices & Nilai & Cutoff & Kriteria \\
\hline Chi-square & 67,447 & Diharapkan rendah & Fit \\
\hline Probability & 0,185 & $>0,05$ & Fit \\
\hline CMINDF & 1,163 & $<2$ & Fit \\
\hline CFI & 0,99 & $>0,9$ & Fit \\
\hline GFI & 0,927 & $>0,95$ & Fit \\
\hline AGFI & 0,888 & $>0,9$ & Fit \\
\hline TLI & 0,984 & $>0,95$ & Fit \\
\hline RMSEA & 0,037 & $<0,08$ & Fit \\
\hline
\end{tabular}


Langkah selanjutnya melakukan uji kausalitas untuk menguji hipotesis penelitian. Berdasarkan Gambar 2, maka interpretasi secara rinci disajikan dalam Tabel 3.

Tabel 3. Hasil Pengujian Hipotesis

\begin{tabular}{|l|c|c|c|}
\hline \multicolumn{1}{|c|}{ Hipotesis } & Nilai C.R & Nilai $p$ & Keterangan \\
\hline Event Sport Tourism $\rightarrow$ Perceived Value & $-1,398$ & 0,162 & Tidak Signifikan \\
\hline Citra Destinasi Halal $\rightarrow$ Perceived Value & 2,283 & 0,022 & Signifikan \\
\hline Event Sport Tourism $\rightarrow$ Behavioral Intentions & 2,101 & 0,036 & Signifikan \\
\hline Citra Destinasi Halal $\rightarrow$ Behavioral Intentions & 1,862 & 0,063 & Tidak Signifikan \\
\hline Perceived Value $\rightarrow$ Behavioral Intentions & $-0,791$ & 0,429 & Tidak Signifikan \\
\hline
\end{tabular}

1) Hipotesis 1 : Event sport tourismtidak berpengaruh signifikan terhadap perceived value, hipotesis ditolak.

Hasil analisis SEM menunjukkan bahwa event sport tourism tidak berpengaruh signifikan terhadap perceived value dimana didapatkan arah hubungan negatif. Hal ini terlihat dari nilai CR sebesar sebesar -1,398 dengan nilai $p(0,162)>0,05$. Dengan demikian Event Sport Tourismmemiliki pengaruh tidak signifikan terhadap perceived value.

2) Hipotesis 2 : Citra destinasi halal berpengaruh positif dan signifikan terhadap perceived value, hipotesis diterima.

Citra destinasi halal berpengaruh positif dan signifikan terhadap perceived valuedimana didapatkan arah hubungan positif. Hal ini terlihat dari nilai C.R. sebesar 2,283 dengan nilai $p(0,022)<0,05$, sehingga keputusan yang diambil adalah menerima $\mathrm{H} 2$. Artinya citra destinasi halal berpengaruh signifikan terhadap perceived value.

3) Hipotesis 3:Event sport tourism berpengaruh positif dan signifikan terhadap behavioral intentions, dapat diterima.

Berdasarkan hasil analisis terlihat dari nilai C.R. sebesar 2,283 dengan nilai $p(0,022)<$ 0,05 , sehingga keputusan yang diambil adalah menerima H3. Artinya halal destination imageberpengaruh signifikan terhadap perceived value.

4) Hipotesis 4: Citra destinasi halal tidak berpengaruh signifikan terhadap behavioral intentions, hipotesis ditolak.

Hasil analisis SEM menunjukkan citra destinasi halal tidak berpengaruh signifikan terhadap behavioral intentions. Hal ini terlihat dari nilai C.R. sebesar 1,862 dengan nilai $p$ $(0,063)>0,05$, sehingga keputusan yang diambil adalah menolak H4. Artinya citra destinasi halal tidak berpengaruh signifikan terhadap behavioral intentions.

5) Hipotesis 5:Perceived value tidak berpengaruh signifikan terhadap behavioral intentions, hipotesis ditolak.

Perceived value tidak berpengaruh signifikan terhadap behavioral intentions. Hal ini terlihat dari nilai C.R. sebesar -0,791 dengan nilai $p(0,429)>0,05$, sehingga keputusan yang diambil adalah menolak H5. Artinya perceived value tidak berpengaruh signifikan terhadap behavioral intentions.

\subsection{Pembahasan}

Penelitian ini mengkaji keterkaitan antara event sport tourism, citra destinasi halal, perceived value, dan behavioral intention. Penelitianini memiliki beberapa implikasi teoritis yang signifikan bagi penelitian pariwisata, khususnya event pariwisata olahraga. Salah satu implikasi teoritis dari penelitian ini adalah lanjutan dari penelitian (Jin, Lee, \& Lee, 2013). Jin, Lee, \& Lee (2013) menemukan bahwa eventmemiliki pengaruh positif terhadap behavioral jmm.unram.ac.id 
intentions, berlaku untuk konteks event sport tourism. Event Sport Tourism memiliki peran penting di dalam memunculkan niat berperilaku berkunjung kembali wisatawan (behavioral intentions to revisit) karena mampu memberikan pengalaman kepada wisatawan yang mengikuti event maupun penonton dari event tersebut.Selanjutnya, penelitian (Milovanović, Matić, Alexandris, Maksimović, Milošević, \& Drid, 2019) memperkuat pentingnya kualitas event, karena secara langsung memprediksi behavioral intentionswisatawan. Jeong, Kim, \& Yu (2019) menunjukkan manfaat kualitas event dalam penelitian yang bertujuan untuk lebih memahami dan memprediksi niat perilaku wisatawan. Selain itu, Lita (2015) menyimpulkan bahwa kepuasan terhadap sport event berpengaruh terhadap behavioral intentions to revisit. dari hasil penelitian (Lita \& Ma'ruf, 2014) ditemukan bahwa kepuasan terhadap sport event berpengaruh positif terhadap intensi berkunjung kembali dan kepuasan terhadap sport event berpengaruh positif terhadap intense untuk positive word-of-mouth. Hasil penelitian sebelumnya event sport tourism mampu meningkatkan behavioral intentions wisatawan di masa yang akan datang yaitu intensi untuk mengunjungi kembali ke destinasi wisata dan mau merekomendasikan kepada orang lain (teman dan keluarga). Oleh karena itu pihak penyelenggara event sport tourism benar-benar berupaya memberikan kualitas event yang baik sehingga memberikan kepuasan kepada wisatawan yang mengikuti dan menonton event tersebut.

Selain itu, hasil penelitian menunjukkan citra destinasi halal berpengaruh positif dan signifikan terhadap perceived value. Ini berarti hipotesis penelitian terjawab dan dapat dibuktikan bahwa terdapat pengaruh positif dan signifikan antara citra destinasi halal terhadap perceived value. Artinya semakin bagus citra destinasi halal maka akan semakin bagus juga perceived value pada event Mandalika International Marathon, demikian sebaliknya jika implementasi citra destinasi halalsemakin buruk maka akan semakin buruk juga perceived value.Hasil penelitian ini juga konsisten dengan penelitian yang dilakukan oleh (Cipta \& Farida, 2018) menemukan bahwa dimensi citra destinasi mengenaikerapian, kebersihan objek wisata dan kesan positif yang diperoleh saat kunjungan berpengaruh positif signifikan terhadap variabel perceived value. Demikian juga penelitian yang dilakukan oleh Jin, Lee, \& Lee (2013) hasilnya citra destinasi dan perceived value memiliki efek positif. Adanya pengaruh positif berarti semakin meningkat perceived value. Penelitian mengenai citra destinasi terhadap perceived value juga diteliti oleh (Kim, Lee, Petrick, \& Hahn (2018), yang menunjukkan hasil bahwa citra destinasi berpengaruh positif dan signifikan terhadap perceived value. Pengaruh citra destinasi halal $(\mathrm{X} 2)$ terhadap persepsi nilai $(\mathrm{Z})$ juga didukung dari kesesuaian antara nilai yang dibayarkan dengan fasilitas yang ada.

Selanjutnya, event sport tourism berpengaruh negatif dan tidak signifikan terhadap perceived value. Kualitas event tidak merubah nilai persepsi para peserta yang mengikuti event sport tourism. Mengacu pada kajian sebelumnya, hasil penelitian ini bertolak belakang dengan penelitian sebelumnya oleh (Chen \& Chen, 2010), yang menunjukkan peran penting event dalam mempengaruhi perceived value pelanggan dan perilaku konsekuen. Penelitian (Jin, Lee, \& Lee, 2013) juga menemukan hubungan event berpengaruh positif terhadap perceived value. Zona ketidakpedulian terjadi pada wisatawan yang merasakan kualitas dari event sport tourism atau mendapatkan pengalaman yang setara sesuai dengan ekspektasi, wisatawan tersebut cenderung tidak peduli dengan nilai yang dibayarkan. Hasil penelitian ini dapat dipengaruhi oleh karakteristik responden, dimana responden dengan pekerjaan sebagai PNS/TNI/POLRI memiliki presentase tertinggi sehingga menunjukkan pengaruh negatif tidak signifikan. Peserta aktif maupun peserta pasif yang merupakan seorang PNS/TNI/POLRI yang mempunyai penghasilan tetap tidak peduli nilai yang mereka bayar 
terhadap event yang mereka ikuti. Selagi kualitas event tersebut sesuai dengan nilai yang mereka bayarkan.

Sedangkan, citra destinasi halal berpengaruh positif tetapi tidak signifikan terhadap behavioral intentions. Secara teoritis hasil penelitian ini mendukung pendapat Fadiryana \& Chan (2019) citra destinasi tidak memiliki pengaruh yang signifikan terhadap niat berperilaku untuk berkunjung kembali pada destinasi wisata halal di kota Banda Aceh. Kim, Lee, Petrick, \& Hahn (2018), juga menemukan citra destinasi tidak berpengaruh positif dan signifikan terhadap behavioral intentions. Penelitian mengenai citra destinasi juga diteliti oleh (Jin, Lee \& Lee, 2015) dengan hasil pengaruh dari citra destinasi terhadap behavioral intention tidak menunjukkan effect signifikan. Ekspektasi dari penelitian ini adalah citra destinasi halal dapat menjadi prediktor penting dari behavioral intentions bersama dengan variabel lain, sepertievent sport tourism dan perceived value tapihasil tidak mengidentifikasi citra destinasi halal sebagai anteseden penting dari event sport tourism.

Kemudian, perceived valuejuga tidak berpengaruh signifikan terhadap behavioral intentions wisatawan. Hasil penelitian ini mendukung pendapat Jin, Lee \& Lee (2015) bahwa perceived value tidak menunjukkan pengaruh signifikan.terhadap behavioral intentions. Dimana $71 \%$ responden berasal dari NTB lebih nilai yang dibayarkan tidak akan mempengaruhi behavioral intentions mereka untuk datang kembali atau merekomendasikan event tersebut kepada orang lain. Mereka tidak akan mengeluarkan dana seperti wisatawan dari daerah lain, misalnya seperti biaya penginapan dan biaya akomodasi.

\section{KESIMPULAN DAN SARAN}

\subsection{Kesimpulan}

Adapun kesimpulan dari hasil penelitian ini adalah sebagai berkut :

1. Event Sport Tourism tidak berpengaruh signifikan terhadap Perceived Value, dimana hipotesis pertama tidak terbukti atau tidak dapat diterima. Hasil ini berarti bahwa event sport tourism tidak memberikan kontribusi dalam perceived value peserta.

2. Citra Destinasi Halal berpengaruh positif signifikan terhadap Perceived Value. sehingga hipotesis kedua dapat diterima. Hal ini bermakna bahwa jika implementasi Citra Destinasi Halal semakin bagus, dapat meningkatkan Perceived Value pada peserta atau wisatawan. Begitu juga sebaliknya.

3. Event Sport Tourism berpengaruh positif signifikan terhadap Behavioral Intention, dengan demikian hipotesis ketiga yang diajukan terbukti. Semakin sering diadakan Event Sport Tourism tentunya akan ikut meningkatkan Behavioral Intentions wisatawan, begitu juga sebaliknya jika pengadaan Event Sport Tourism jarang akan mengurangi Behavioral Intention wisatawan.

4. Variabel Citra Destinasi Halal berpengaruh positif tidak signifikan terhadap behavioral intentions wisatawan. Dimana hipotesis yang diajukan tidak terbukti atau tidak dapat diterima. Hasil ini berarti bahwa semakin bagus Citra Destinasi Halal hanya dapat memberikan kontribusi yang rendah dalam meningkatkan behavioral intentions pada kunjungan wisatawan ke event sport tourism. Sebaliknya jika halal destination image kurang bagus juga tidak akan memberikan dampak yang signifikan terhadap behavioral intentions wisatawan.

5. Variabel Perceived Value tidak berpengaruh signifikan terhadap behavioral intentions wisatawan.

\subsection{Saran}


Penelitian ini menawarkan beberapa implikasi praktis. Karena event sport tourism berpengaruh pada behavioral intentions wisatawan pada event Mandalika International Marathon disarankan bagi penyelenggara, untuk memperhatikan kualitas event. Tidak hanya terfokus pada harga ditawarkan, namun perlu memikirkan bagaimana event sport tourism mampu mempengaruhi niat berperilaku wisatawan untuk berkunjung kembali maupun merekomendasikan kepada orang lain serta positif word of mouth (WOM). Dengan adanya citra sebagai pariwisata halal, tentunya para penyelenggara event harus memperhatikan aspek-aspek nilai Islami pada event tersebut, seperti aturan berpakaian para peserta, adanya pemisahan tempat untuk para peserta, serta pemisahan tim medis bagi peserta laki-laki dan perempuan. Kemudian, pemerintah setempat perlu mendukung upayaupaya para penyelenggara event dalam mengembangkan pariwisata halal dan event sport tourism, untuk lebih memperhatikan fasilitas-fasilitas penunjang yang ada di sekitaran lokasi event terutama fasilitas ibadah. Agar citra destinasi wisata halal yang ada di NTB tidak hanya untuk wisata-wisata religi saja. Untuk kenyamanan para peserta event, baik peserta aktif maupun peserta pasif.Selain itu, perlu adanya aturan mengenai sertifikasi halal dimana pemerintah dapat bekerjasama dengan Lembaga MUI baik di sector makanan maupun di sector akomodasi untuk meyakinkan wisatawan bahwa produk-produk yang ada di lokasi event sport tourism telah menerapkan nilai Islami sebagai bentuk dari citra destinasi halal. Meskipun mampu memberikan pengetahuan baru,penelitian ini memiliki beberapa keterbatasan yang bisa digunakan untuk penelitianselanjutnya. Diharapkan penelitian berikutnya dapat mencakup ruang lingkup yang lebih luas lagi seperti pengambilan lebih banyak sampel peserta pasif serta sampel dari peserta mancanegara agar peneliti dapat mengetahui perbedaan niat berperilaku wisatawan nusantara dengan wisatawan mancanegara.Selain itu pada penelitian lanjutan dapat menggunakan indikator variabel event sport tourism lainnya dan dipadukan dengan citra destinasi halal untuk mengetahui perceived value serta behavioral intentions wisatawan. Meskipun event sport tourism sangat menarik bagi penyelenggara event, hanya sedikit penelitian empiris yang telah membahas konsekuensi perilaku potensial yang timbul dari event sport tourism. Untuk memperluas pemahaman tentang hubungan antara event sport tourism dan behavioral intentios wisatawan, moderator potensial lainnya seperti, faktor situasional dan perbedaan budaya, dapat dipertimbangkan dalam penelitian selanjutnya. 


\section{DAFTAR PUSTAKA}

Afrilian, P. (2018). Pengaruh Kesuksesan Penyelenggaraan Event Sport Tourism Triathlon Pariaman Dalam Meningkatkan Kunjungan Wisatawan Mancanegara Dari Tahun 2014 Sampai Tahun 2017. Jurnal Stamina, 1(1), 12-23.

Annisa, Z. P. (2016). Pengaruh Citra Sport Event, Citra Destinasi, Dan Tingkat Kepuasan Terhadap Loyalitas Wisatawan Pada Event Paralayang Di Puncak Lawang Agam Sumatera Barat (Doctoral Dissertation, Universitas Andalas).

Battour, M., \& Ismail, M. N. (2016). Halal tourism: Concepts, practises, challenges and future. Tourism management perspectives, 19, 150-154.

Chen, C. F., \& Chen, F. S. (2010). Experience quality, perceived value, satisfaction and behavioral intentions for heritage tourists. Tourism management, 31(1), 29-35.

Chen, R. S., \& Tsai, C. C. (2007). Gender differences in Taiwan university students' attitudes toward web-based learning. Cyberpsychology \& behavior, 10(5), 645-654.

Cipta, S. R., \& Farida, N. (2018). Pengaruh Destination Image, Fasilitas Wisata, Dan Perceived Value Terhadap Behavioral Intentions (Studi Pada Pengunjung Taman Wisata Kopeng). Jurnal Ilmu Administrasi Bisnis, 7(3), 221-225.

Destari, F. (2017).Meningkatkan Intention to Revisit Melalui Keunikan Jasa Pariwisata \& Destination Image. Jurnal Manajemen dan Kearifan Lokal Indonesia, 1(1), 44-58.

Dshauma, J. L., Wilopo, W., \& Alfisyahr, R. (2018). Analisis Manajemen Event Pariwisata Olahraga Bromo Marathon (Studi Kasus Pada Daerah Tujuan Wisata Bromo Tengger Semeru). Jurnal Administrasi Bisnis, 64(1), 109-118.

Fadiryana, N. A., \& Chan, S. (2020). Pengaruh Destination Image Dan Tourist Experience Terhadap Revisit Intention Yang Dimediasi Oleh Perceived Value Pada Destinasi Wisata Halal Di Kota Banda Aceh. Jurnal Manajemen Inovasi, 10(2).

Fu, Y., Liu, X., Wang, Y., \& Chao, R. F. (2018). How experiential consumption moderates the effects of souvenir authenticity on behavioral intention through perceived value. Tourism Management, 69, 356-367.

Gibson, H. J. (1998). Active sport tourism: who participates?. Leisure studies, 17(2), 155-170.

Gibson, H. J. 1998. Sport tourism: a critical analysis of research. Sport Management Review, 1(1): 45-76.

Gohary, H. (2016). Halal tourism, is it really Halal?. Tourism Management Perspectives, 19, 124130.

Hussein, A. S. (2016). How Event Awareness, Event Quality and Event Image Creates Visitor Revisit Intention?: A Lesson from Car free Day Event. Procedia Economics and Finance, 35, 396-400.

Indira, D., Ismanto, S. U., \& Santoso, M. B. (2013). Pencitraan Bandung Sebagai Daerah Tujuan Wisata: Model Menemukenali Ikon Bandung Masa Kini. Sosiohumaniora, 15(1), 45-54.

Jeong, Y., Kim, S. K., \& Yu, J. G. (2019). Determinants of behavioral intentions in the context of sport tourism with the aim of sustaining sporting destinations. Sustainability,11(11), 3073.

Jin, N., Lee, H., \& Lee, S. (2013). Event quality, perceived value, destination image, and behavioral intention of sports events: The case of the IAAF World Championship, Daegu, 2011. Asia Pacific Journal of Tourism Research, 18(8), 849-864.

Jin, N., Lee, S., \& Lee, H. (2015). The effect of experience quality on perceived value, satisfaction, image and behavioral intention of water park patrons: New versus repeat visitors. International Journal of Tourism Research, 17(1), 82-95 
Kaur, A., Chauhan, A., \& Medury, Y. (2016). Destination image of Indian tourism destinations: An evaluation using correspondence analysis. Asia Pacific Journal of Marketing and Logistics, 28(3), 499-524.

Kim, M. J., Lee, C. K., Petrick, J. F., \& Hahn, S. S. (2018). Factors affecting international event visitors' behavioral intentions: the moderating role of attachment avoidance.Journal of Travel E Tourism Marketing, 35(8), 1027-1042.

Kotler, P., \& Keller, K. (2011). Marketing management 14th edition. Prentice Hall.

Kristanti, L. T., \& Farida, N. (2016). Pengaruh Citra Destinasi dan Fasilitas Wisata terhadap Niat Berperilaku Melalui Kepuasan Sebagai Variabel Intervening (Studi pada Pengunjung Museum Kereta Api Ambarawa). Jurnal Ilmu Administrasi Bisnis, 5(3), 117-126.

Kurtzman, J. (2005). Economic impact: sport tourism and the city. Journal of Sport Tourism, 10(1), 47-71

Lita, R. P. (2015). Relationship Model Among Sport Event Image, Destination Image, And Tourist Satisfaction Of Tour De Singkarak In West Sumatera. Journal Of Economics, Business \& Accountancy Ventura (Jebav), 18(1), 91-102.

Lita, R. P., \& Ma'ruf, M. R.(2014). The Relationship Between Satisfaction With The Sport Event, Revisit Intention And Positive Word-Of-Mouth Intention; The Study Of Dragon Boat Sport Event In Padang City.

Mason, M. C., Moretti, A., Raggiotto, F., \& Paggiaro, A. (2019). Conceptualizing triathlon sport event travelers' behavior.

Milovanović, I., Matić, R., Alexandris, K., Maksimović, N., Milošević, Z., \& Drid, P. (2019). Destination Image, Sport Event Quality, and Behavioral Intentions: The Cases of Three World Sambo Championships. Journal of Hospitality $\mathcal{E}$ Tourism Research, 1096348019883920.

Mowen, J. C., \& Minor, M. (2002). Perilaku konsumen. Jakarta: Erlangga, 90.

Paramitha, S. T., \& Sukirman, O. (2019, June). Tour de Linggarjati: The Model of Effective International Tourism Promotion through Sport Tourism Events. In 3rd International Seminar on Tourism (ISOT 2018). Atlantis Press.

Prayag, G., Hosany, S., \& Odeh, K. (2013). The role of tourists' emotional experiences and satisfaction in understanding behavioral intentions. Journal of Destination Marketing $\mathcal{E}$ Management, 2(2), 118-127.

Samsudin, A. (2016). Analysing The Effects Of Destination Image And Tourist Satisfaction On Revisit Intention In Case Bunaken National Park. Jurnal Berkala Ilmiah Efisiensi, 16(4).

Woodruff, R. B. (1997). Customer value: the next source for competitive advantage. Journal of the academy of marketing science, 25(2), 139.

Yohanes, Y. G. (2018) Pengaruh Event Terhadap Revisit Intention Dengan Destination Image Dan Customer Experience Sebagai Variabel Intervening (Studi Pada Event Gawai Dayak Kota Pontianak). Jurnal Manajemen Update, 7(2).

Zeithaml, V. A., Berry, L. L., \& Parasuraman, A. (1996). The behavioral consequences of service quality. Journal of marketing, 60(2), 31-46

Kepala Dinas Pariwisata NTB. 2016. "Wisata Halal dan Turisme Olahraga Jadi Andalan Lombok", diakses pada tanggal 10 November 2019 dari https://republika.co.id/berita/gaya-hidup/wisata-halal/16/12/04/ohnzjv328wisata-halal-dan-turisme-olahraga-jadi-andalan-lombok 